\title{
Analisis Appraisal Teks Editorial Pangudarasa dalam Majalah Panjebar Semangat
}

\author{
Kenfitria Diah Wijayanti ${ }^{1}$ \\ ${ }^{1}$ Doctoral Student of Linguistics Graduate Program, \\ Universitas Sebelas Maret, Surakarta, Indonesia
}

\begin{tabular}{l} 
Article Info \\
\hline Article history: \\
Submitted Dec 30, 2019 \\
Revised Jan 28, 2020 \\
Accepted Oct 24, 2020 \\
Published Nov 02, 2020
\end{tabular}

\section{Keywords:}

Appraisal

Attitude

Affect

Apreciation

Amplification

\begin{abstract}
This article explores Pangudarasa's editorial texts in the Panjebar Semangat magazine by using a systemic theory of functional linguistics particularly an appraisal analysis of texts. The objectives of this research are (1) to identify the appraisal tools in Pangudarasa's editorial texts in a Javanese magazine called Panjebar Semangat, and (2) to describe the perceptions of Pangudarasa's editorial text writers in the Panjebar Semangat magazine. This descriptive qualitative research used a qualitative method along with a content analysis platform. The data pertaining to words, phrases, clauses, and sentences coincided with appraisal tools. The data source was derived from the Panjebar Semangat magazine, which was published on December 21, 2019 entitled Kasus Garuda, Wanci Kang Pas Kanggo Ngresiki BUMN. The data analysis used a method of referential matching tools to determine a phenomenon beyond the language. The results of data analysis show that (1) appraisal tools in the editorial texts of Pangudarasa in the Panjebar Semangat magazine dominantly present appreciation (42.55\%), judgment (36.17\%) and affect (21.28\%), and (2) the pattern of writers' perceptions to support the Minister Erick Thohir's decision in handling the Garuda Airlines case. This support is reinforced by the use of language functions to influence others by assessing a case directly and authors of editorial texts have a tendency to tell sensitive things or issues mainly concerned with events in the community.
\end{abstract}

\section{Corresponding Author:}

Kenfitria Diah Wijayanti,

Doctoral Student of Linguistics Graduate Program Universitas Sebelas Maret

Jl. Ir. Sutami 36 A, Kentingan, Surakarta, Indonesia.

Email: kenfi3a@ymail.com

\section{PENDAHULUAN}

Majalah berbahasa Jawa masih memiliki pembaca setia yaitu masyarakat Jawa Tengah, Yogyakarta, dan Jawa Timur. Majalah Panjebar Semangat merupakan majalah berbahasa Jawa berskala lokal Surabaya-Jawa Timur yang terbit secara berkala dalam satu minggu sekali. Majalah ini dirintis oleh Dr. Soetomo Maha Putra yakni pendiri Boedi Oetomo pada tanggal 2 September 1933. Majalah Panjebar Semangat yang kemudian disingkat dengan PS menyajikan tulisan yang beragam yakni berupa berita lokal maupun nasional, editorial, ulasan budaya, karya sastra, dsb. Pangudarasa merupakan sebuah judul teks editorial yang terdapat dalam majalah PS. Di dalam Pangudarasa terdapat opini penulis terhadap sebuah masalah yang aktual dan faktual. Tulisan bersifat argumentatif, sehingga sesuai dengan kebutuhan analisis appraisal.

Teori appraisal menjadi bagian dari kajian linguistik sistemik fungsional yang fokus pada evaluasi bahasa, sikap dan emosi, serta bagaimana suatu teks memiliki tujuan dan masalah secara interpersonal (Martin \& White, 2005). Di sisi lain appraisal dapat difungsikan sebagai alat untuk membedah teks dalam critical discourse analysis seperti 
yang diungkap oleh Fairclough (2001) yakni The discussion of issue and problems in critical discourse analysis which will occupy the rest of this introduction will be organized around the three dimensions of the analytical framework sketched out above: text, discourse practice, and sosiocultural practice. Piranti sosiokultural merupakan unsur yang digunakan dalam analisis appraisal. Analisis apraisal meliputi tiga hal yaitu sikap, pemosisian, dan graduasi. Dalam penelitian terfokus analisis appraisal pada teks editorial Pangudarasa dalam majalah PS yang terbit pada tanggal 21 Desember 2019 dengan judul Kasus Garuda, Wanci Kang Pas Kanggo Ngresiki BUMN. Appraising items atau perangkat appraisal menunjukkan pemarkah appraisal meliputi sikap, pemosisian, dan graduasi. Appraiser adalah pihak yang menuturkan pemarkah appraisal. Dalam teks editorial Pangudarasa ini yang menjadi penutur adalah penulis (Ksw) dengan label majalah Panjebar Semangat. Sementara itu, appraised adalah pihak yang menjadi target appraiser. Pihak yang menjadi target adalah pembaca setia majalah Panjebar Semangat yaitu masyarakat Jawa Tengah-Jawa TimurYogyakarta usia dewasa. Attitude yakni salah satu unsur pemarkah dalam appraisal yang memperlihatkan sebuah teks dapat menunjukkan karakter atau sikap seseorang. Engagement merupakan pemarkah dalam appraisal yang mengacu pada keterikatan antara apa yang dikatakan atau ditulis seseorang dengan makna yang ditangkap oleh pendengar atau pembacanya. Graduation merupakan pemarkah dalam appraisal yang menunjukkan adanya tingkatan makna dalam suatu teks, yaitu makna naik atau turun. Affect merupakan salah satu bagian dari pemarkah attitude yang menjelaskan bagaimana seorang pembicara atau penulis menyampaikan emosi yang dirasakannya. Judgement adalah bagian dari pemarkah attitude tentang bagaimana menilai kepribadian seseorang, dilihat dari norma sosial. Appreciation adalah bagian dari pemarkah attitude tentang bagaimana menilai suatu objek dan produk dengan memperhatikan prinsip keindahan dan sistem nilai sosial lain.

Beberapa penelitian serupa pernah dilakukan antara lain yaitu penelitian Rusyda, dkk (2016) yang berjudul Apraisal Sikap dalam Teks Berita Surat Kabar Nasional. Penelitian ini bertujuan untuk 1) menggambarkan pola sikap pada teks berita dari koran harian Media Indonesia, koran Republika, koran harian Kompas, dan 2) menjelaskan mengapa sikap pola seperti itu dalam teks berita dari koran harian Media Indonesia, koran Republika, koran harian Kompas. Berdasarkan hasil analisis data diperoleh hasil 1) pola sikap appraisal di koran harian Media Indonesia dan koran harian Republika, apresiasi 'afek' penilaian, dan koran harian Kompas, afek 'apresiasi' penilaian. Kecenderungan penggunaan pola sikap leksis negative menunjukkan penulis koran berita nasional, dan 2) pola kecenderungan sikap terjadi karena penulis sering menggunakan fungsi Bahasa untuk memengaruhi orang lain dengan memberikan penilaian langsung terhadap suatu hal dan penulis berita koran nasional memiliki kecenderungan menceritakan peristiwa sensitif atau masalah yang menimbulkan keprihatinan terhadap peristiwa-peristiwa yang terjadi di masyarakat.

Penelitian berikutnya dilakukan oleh Ellyawati (2011) dengan judul Analisis Wacana Kritis Teks Berita Kasus Terbongkarnya Perlakuan Istimewa terhadap Terpidana Suap Arthalyta Suryani pada Media Online. Penelitian ini bertujuan untuk menganalisis liputan tentang kasus terungkapnya perlakuan istimewa terhadap Arthalyta Suryani, seorang terpidana suap yang ditahan di Pondok Bambu yang ditulis oleh dua media online yaitu detikNews.com dan Kompas.com dengan menganalisis sistem penilaian dan intertekstualitas media online tersebut. Berdasarkan analisis data yang telah dilakukan menunjukkan ideologi dua media tentang kasus ini dapat terlihat. Ideologi memiliki hubungan dekat dengan target pasar yaitu pembaca. detikNews.com adalah berita langsunng dan pendek, dengan pilihan kosa kata yang tajam, mereka terkait dengan genre item berita yang dimiliki, tetapi media ini kurang intertekstualitas. Hal itu menjadikan sifat pemberitaannya dangkal. Di sisi lain Kompas.com memiliki jangkauan yang dalam dan 
intertekstualitas yang kuat, sangat cocok untuk seseorang yang menginginkan informasi yang komprehensif.

Penelitian ketiga dilakukan oleh Pusparini, dkk (2017) dengan judul Analisis Sistem Appraisal Berita Proses Eksekusi Duo Bali Nine (Pendekatan Linguistik Sistemik Fungsional). Data diperoleh dalam teks berita yang mengungkap masalah eksekusi Duo Bali Nine yang diambil dari The Sydney Morning Herald, The Guardian Australia, The Jakarta Globe dan The Jakarta Post. Penelitian ini bertujuan untuk mendeskripsikan sistem penilaian yang diterapkan dalam teks-teks berita tersebut, dan untuk mengetahui posisi wartawan melalui teks-teks berita mereka, serta pengaruh sistem penilaian terhadap pembaca. Hasil penelitian menunjukkan bahwa setiap surat kabar memiliki pola sistem peneliaian yang berbeda. Semua jenis sikap diterapkan dalam teks berita baik positif maupun negatif. Engagement merupakan sebagian dari heteroglos. Penggunaan heteroglos seolah membuat jurnalis dalam posisi netral, sehingga pembaca lebih mudah menangkap pesan berita tersebut.

Penelitian yang selanjutnya dilakukan oleh Irlinda, dkk (2016) dengan judul Analisis Terjemahan Ekspresi Solidaritas dan Keberpihakan dalam Teks Konferensi Pers dan Siaran Media Tentang Eksekusi Narapidana (Pendekatan Teori Appraisal). Penelitian ini bertujuan untuk 1)mengidentifikasi teknik penerjemahan piranti appraisal dan dampaknya terhadap kualitas terjemahan; 2) memaparkan piranti appraisal yang merealisasikan nilai solidaritas dan keberpihakan pada teks konferensi pers dan siaran media dalam Bahasa Inggris dan terjemahannya dalam Bahasa Indonesia; 3) mengelaborasi posisi partisipan berdasarkan kerangka teori appraisal dan menjelaskan jika pemosisian tersebut dipertahankan, digeser, diubah, dihilangkan, atau ditambah di dalam teks sasaran. Berdasarkan analisis data yang telah dilakukan diperoleh hasil bahwa terjemahan dapat menimbulkan interferensi atau bahkan distorsi dari pesan teks sumber.

Penelitian kelima dilakukan oleh Panggabean (2016) yang berjudul Evaluasi Bahasa Tajuk Rencana Menggunakan Kerangka Apraisal oleh Mahasiswa Program Studi Pendidikan Bahasa dan Sastra Indonesia FKIP Universitas HKBP Nommensen. Penelitian ini bertujuan untuk mengevaluasi Bahasa teks tulisan berupa tajuk rencana dari koran dengan memerhatikan sikap dan pemosisian pada tulisan. Hasil penelitian menunjukkan bahwa pola apraisal dalam teks tajuk rencana harian Analisa dalam menuliskan pesannya di dalam teks editorial banyak menggunakan fungsi bahasa menguatkan atau melemahkan sikap dan pemosisian yang dihubungkan oleh teks.

Penelitian ini memiliki objek kajian berbeda dengan beberapa penelitian terdahulu yang telah dilakukan. Teks editorial Pangudarasa pada majalah mingguan Panjebar Semangat yang dijadikan objek menggunakan Bahasa Jawa. Hal tersebut menjadi gap dari penelitian-penelitian sebelumnya. Penggunaan Bahasa Jawa pada teks editorial menunjukkan keunikan dan kekhasan tersendiri, apalagi Bahasa yang digunakan adalah Bahasa Jawa Timuran yang memiliki ciri lugas dan tegas. Penelitian ini bertujuan untuk (1) mengidentifikasi piranti appraisal yang terdapat pada teks editorial Pangudarasa dalam majalah berbahasa Jawa Panjebar Semangat, dan (2) untuk mendeskripsikan persepsi penulis teks editorial Pangudarasa dalam majalah berbahasa Jawa Panjebar Semangat.

\section{TEORI DAN METODOLOGI}

Penelitian ini bersifat deskriptif kualitatif. Metode penelitian yang digunakan yaitu metode kualitatif dengan analisis isi. Sampel penelitian ini adalah teks editorial Pangudarasa dalam majalah Panjebar Semangat edisi 21 Desember 2019 dengan judul Kasus Garuda, Wanci Kang Pas Kanggo Ngresiki BUMN. Data yang digunakan yaitu kata, frasa, klausa, dan kalimat yang 
mengandung appraisal. Sumber data diperoleh dari majalah Panjebar Semangat terbit pada tanggal 21 Desember 2019. Pengumpulan data menggunakan teknik simak dan catat (Sudaryanto, 2015) dengan cara melakukan penyimakan pada teks editorial Pangudarasa pada majalah Panjebar Semangat. Analisis data menggunakan metode padan refensial dengan alat penentunya fenomena di luar bahasa. Langkah pertama analisisnya yakni dengan memadankan kata, frasa, klausa, dan kalimat dengan piranti appraisal. Berikutnya mendeskripsikan sikap dan penilaian penulis teks editorial Pangudarasa terhadap keputusan Menteri Erick Thohir terhadap maskapai Garuda.

\section{HASIL DAN PEMBAHASAN}

Teks editorial Pangudarasa yang terdapat dalam majalah Panjebar Semangat edisi 21 Desember 2019 memiliki kekhasan yakni dibuat dengan bahasa singkat, lugas, dan mengandung aspek-aspek appraisal yang memengaruhi persepsi pembacanya. Berikut temuan data pemarkah atau piranti appraisal.

Tabel 1. Jumlah Data Temuan Piranti Appraisal

\begin{tabular}{lc}
\hline \multicolumn{1}{c}{ Piranti Appraisal } & Temuan Data \\
\hline \hline 1) Attitude & \\
a. Affect & 2 \\
i. Affect positif langsung & 4 \\
ii. Affect positif tersirat & 1 \\
iii. Affect negatif langsung & 3 \\
iv. Affect negatif tersirat & 2 \\
b. Judgement & - \\
i. Moral Judgement Positif langsung & 5 \\
ii. Moral Judgement Positif tersirat & 1 \\
iii. Moral Judgement negatif langsung & 4 \\
iv. Moral Judgement negatif tersirat & 1 \\
v. Personal Judgement Positif langsung & 3 \\
vi. Personal Judgement Positif tersirat & 1 \\
vii. Personal Judgement negatif langsung & \\
viii. Personal Judgement negatif tersirat & 3 \\
c. Apreciation & 17 \\
i. Appreciation positif & \\
ii. Appreciation negatif & \\
2. Amplification & 10 \\
a. Force & 6 \\
i. Intensifier & 4 \\
ii. Attitudinal Lexis & 1 \\
iii. Metaphor & \\
iv. Swearing & 3 \\
b. Focus & 2 \\
i. Sharphen & \\
ii. Soften & 2 \\
3. Source of appraisal & 7 \\
a. Monogloss & \\
b. Heterogloss & \\
\hline &
\end{tabular}

Sebanyak 47 data yang ditemukan, didominasi oleh apreciation sebanyak 42,55\%, didapati juga judgement sebanyak 36,17\%, dan affect sebesar 21,28\%. Berikut 
kategorisasi pemarkah atau piranti appraisal yang teridentifikasi di dalam teks editorial Pangudarasa yang terdapat dalam majalah Panjebar Semangat edisi 21 Desember 2019.

Tabel 2. Piranti Appraisal yang teridentifikasi di dalam teks Editorial Pangudarasa di dalam majalah Panjebar Semangat

\begin{tabular}{|c|c|}
\hline Piranti Appraisal & Temuan Data \\
\hline \multicolumn{2}{|l|}{ 1. Attitude } \\
\hline 1.1. Affect & emosi yang dirasakannya \\
\hline 1.1.1. Affect positif langsung & 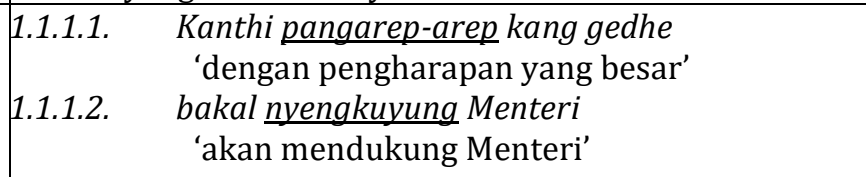 \\
\hline 1.1.2. Affect positif tersirat & 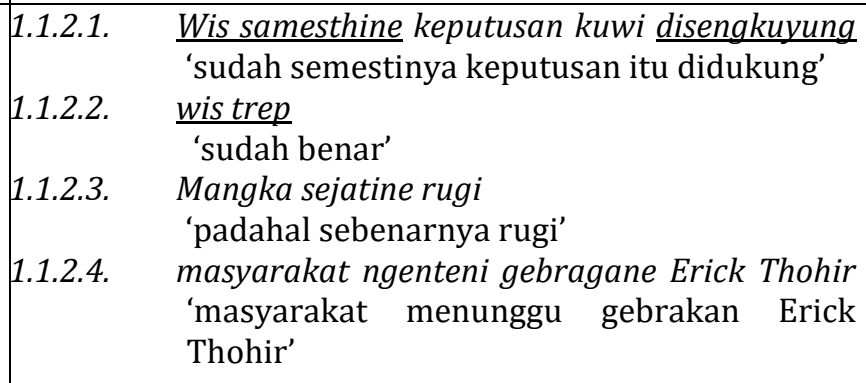 \\
\hline 1.1.3. Affect negatif langsung & $\begin{array}{ll}\text { 1.1.3.1 masyarakat sing wis sebel } \\
\text { 'masyarakat yang sudah jengkel' }\end{array}$ \\
\hline 1.1.4. Affect negatif tersirat & 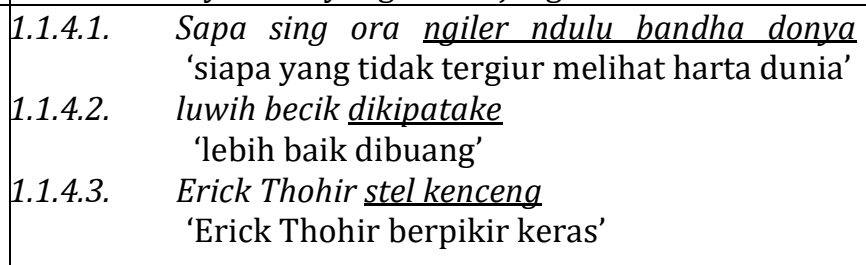 \\
\hline 1.2. Judgement & $\begin{array}{l}\text { menilai kepribadian seseorang, dilihat dari norma } \\
\text { social }\end{array}$ \\
\hline $\begin{array}{l}\text { 1.2.1. Moral Judgement } \\
\text { Positif langsung }\end{array}$ & \begin{tabular}{|l} 
1.2.1.1. \\
$\begin{array}{l}\text { mesthi bakal renes uripe } \\
\text { 'pasti akan sejahtera hidupnya' } \\
\text { paring kawigaten gedhe marang BUMN. } \\
\text { 'memberi perhatian besar pada BUMN' }\end{array}$
\end{tabular} \\
\hline $\begin{array}{l}\text { 1.2.2. Moral Judgement } \\
\text { Positif tersirat }\end{array}$ & \\
\hline $\begin{array}{l}\text { 1.2.3. Moral Judgements } \\
\text { negatif langsung }\end{array}$ & 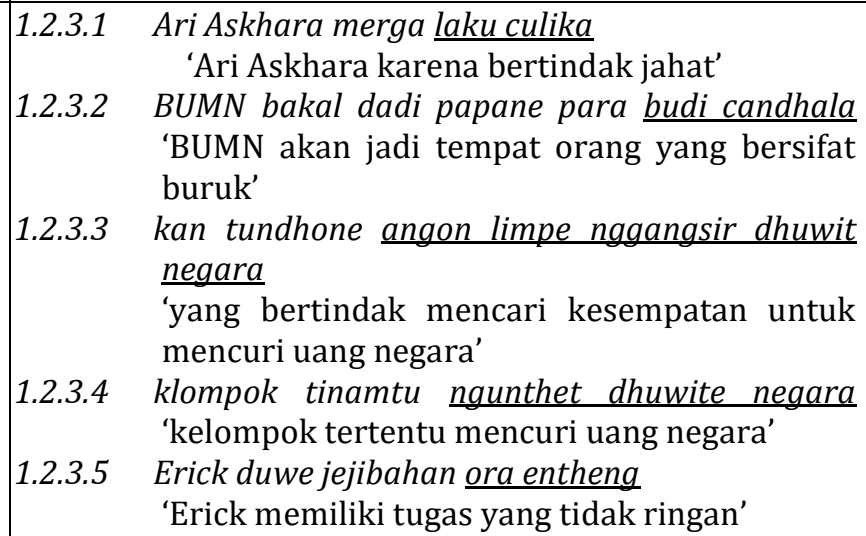 \\
\hline
\end{tabular}




\begin{tabular}{|c|c|}
\hline negatif tersirat & $\begin{array}{l}\text { 'membersihkan BUMN dari jamur-jamur } \\
\text { parasitnya' }\end{array}$ \\
\hline $\begin{array}{l}\text { 1.2.5. Personal Judgement } \\
\text { Positif langsung }\end{array}$ & $\begin{array}{l}\text { Dheweke professional murni } \\
\text { 'Dia professional murni' } \\
\text { Erick Thohir diajab ora duwe sesanggan } \\
\text { politik } \\
\text { 'Erick Thohir diharap tidak memiliki beban } \\
\text { politik' } \\
\text { Dhuwite sing akeh merga kuwat tuku klub bal- } \\
\text { balan } \\
\text { 'Uangnya banyak karena mampu membeli } \\
\text { klub sepak bola' } \\
\text { saengga ora duwe niyat korupsi } \\
\text { 'sehingga tidak memiliki niat untuk korupsi' }\end{array}$ \\
\hline $\begin{array}{l}\text { 1.2.6. Personal Judgement } \\
\text { Positif tersirat }\end{array}$ & $\begin{array}{l}\text { sebab Erick dudu politikus } \\
\text { 'sebab Erick bukan politikus' }\end{array}$ \\
\hline $\begin{array}{l}\text { 1.2.7. Personal Judgement } \\
\text { negatif langsung }\end{array}$ & 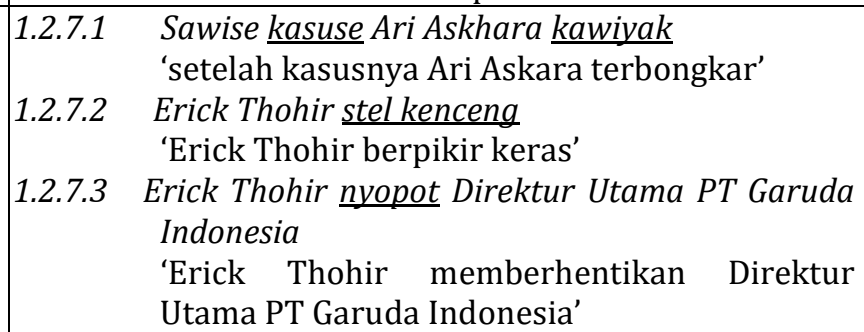 \\
\hline $\begin{array}{l}\text { 1.2.8. Personal Judgement } \\
\text { negatif tersirat }\end{array}$ & $\begin{array}{l}\text { Menteri Erick aja mung mandheg tekan semono } \\
\text { 'Menteri Erick jangan hanya berhenti sampai } \\
\text { di situ' }\end{array}$ \\
\hline 1.3. Apreciation & $\begin{array}{l}\text { menilai suatu objek dan produk dengan } \\
\text { memperhatikan prinsip keindahan dan sistem nilai } \\
\text { sosial lain. }\end{array}$ \\
\hline Appreciation positif & 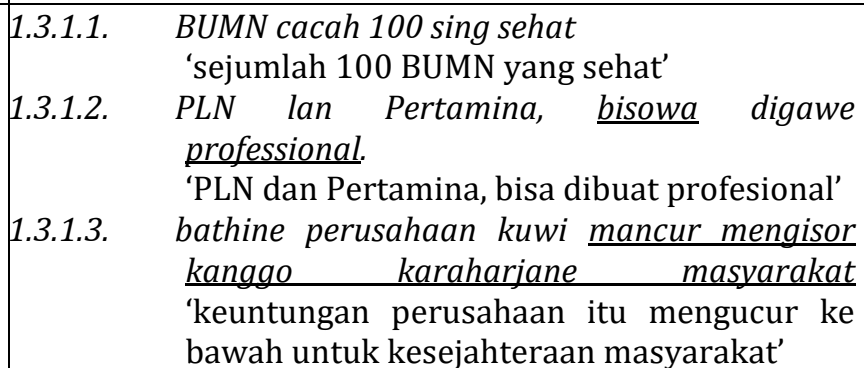 \\
\hline Appreciation negatif & \begin{tabular}{|l} 
1.3.2.1. \\
Kasus korupsi 'legendaris' \\
'kasus korupsi legendaris' \\
1.3.2.2. \\
BUMN sing ora sehat \\
'BUMN yang tidak sehat' \\
1.3.2.3. perusahaan pelat abang cacah atusan nanging \\
uripe ora cetha. \\
'perusahaan plat merah yang berjumlah \\
ratusan tetapi hidupnya tidak jelas.' \\
anak utawa putu perusahaan, dianggep \\
kakehan \\
'anak atau cucu perusahaan dianggap terlalu \\
banyak' \\
ketimbang ngebot-ngeboti kementerian \\
'daripada memberatkan kementerian' \\
ndandani kabeh kebobrokan mental
\end{tabular} \\
\hline
\end{tabular}




\begin{tabular}{|c|c|c|}
\hline & $\begin{array}{l}1.3 .2 .7 . \\
1.3 .2 .8 \\
1.3 .2 .9 \\
1.3 .2 .10 \\
1.3 .2 .11 . \\
1.3 .2 .12 \\
1.3 .2 .13 . \\
1.3 .2 .14 . \\
1.3 .2 .15 \\
1.3 .2 .16 \\
1.3 .2 .17 .\end{array}$ & $\begin{array}{l}\text { 'memperbaiki semua kebobrokan/kerusakan } \\
\text { mental' } \\
\text { pranyata akeh 'tikuse' } \\
\text { 'nyatanya banyak tikusnya' } \\
\text { sawijining BUMN sing diseret } \\
\text { 'salah satu BUMN yang diseret' } \\
\text { masalah BUMN ora bakal ana enteke } \\
\text { 'masalah BUMN tidak aka nada habisnya' } \\
\text { perusahaan siji wae masalahe wis sathekruk } \\
\text { dhewe } \\
\text { 'perusahaan satu saja masalahnya sudah } \\
\text { banyak' } \\
\text { jebul boroke maskapai penerbangan } \\
\text { 'ternyata borok/keburukan maskapai } \\
\text { penerbangan' } \\
\text { malih katon mlaha. } \\
\text { 'menjadi lebih terlihat' } \\
\text { Garuda tau ngakali laporan keuangan } \\
\text { 'Garuda pernah mengakali laporan } \\
\text { keuangan' } \\
\text { Praktek-praktek reged } \\
\text { 'praktik-praktik kotor' } \\
\text { ora tau sepi saka masalah } \\
\text { 'tidak pernah sepi masalah' } \\
\text { klompok tinamtu golek proyek ana kono } \\
\text { 'kelompok tertentu mencari proyek dari } \\
\text { sana' } \\
\text { dudu kanggo klompoke si suta, si naya, si } \\
\text { dhadhap, lan si waru } \\
\text { 'buka untuk kelompok si anak, si pemimpin, } \\
\text { si bunga, si pohon waru (menyebut nama } \\
\text { samaran)' }\end{array}$ \\
\hline \multicolumn{3}{|l|}{ 2. Amplification } \\
\hline 2.1. Force & & \\
\hline 2.1.1. $\quad$ Intensifier & $\begin{array}{l}2.1 .1 .1 . \\
2.1 .1 .2 \\
2.1 .1 .3 . \\
2.1 .1 .4 \\
2.1 .1 .5 \\
2.1 .1 .6 \\
2.1 .1 .7 \\
2.1 .1 .8 \\
2.1 .1 .9 \\
2.1 .1 .10\end{array}$ & $\begin{array}{l}\text { para budi candhala nak kumanak } \\
\text { 'orang-orang yang bersifat buruk beranak- } \\
\text { pinak' } \\
\text { mung mandheg tekan semono } \\
\text { 'hanya berhenti sampai di situ' } \\
\text { Kawit era ordhe lama engga seprene } \\
\text { 'mulai era orde lama sampai sekrang' } \\
\text { asring rinungu } \\
\text { 'sering terdengar' } \\
\text { asete BUMN nggayuh Rp. } 8.000 \text { trilyun } \\
\text { 'asetnya BUMN mencapai Rp. } 8.000 \text { trilyun' } \\
\text { Ora sethithik pimpinan sawijining BUMN } \\
\text { 'tidak sedikit pimpinan salah satu BUMN' } \\
\text { kuwi malih katon mlaha. } \\
\text { 'itu menjadi lebih terlihat' } \\
\text { kuwi asring kedadeyan } \\
\text { 'itu sering terjadi' } \\
\text { Dhuwite sing akeh } \\
\text { 'uangnya yang banyak' } \\
\text { pangarep-arep kang gedhe } \\
\text { 'harapan yang besar' }\end{array}$ \\
\hline
\end{tabular}




\begin{tabular}{|c|c|}
\hline 2.1.2. Attitudinal Lexis & \begin{tabular}{|ll} 
2.1.2.1. & $\begin{array}{l}\text { Kanthi pangarep-arep kang gedhe } \\
\text { 'dengan harapan yang besar' } \\
\text { 2.1.2.2. } \\
\text { bakal nyengkuyung menteri } \\
\text { 'akan mendukung menteri' }\end{array}$ \\
2.1.2.3. & $\begin{array}{l}\text { Wis samesthine keputusan kuwi disengkuyung } \\
\text { 'sudah semestinya keputusan itu didukung' }\end{array}$ \\
2.1.2.4. & $\begin{array}{l}\text { wis trep } \\
\text { 'sudah benar' }\end{array}$ \\
2.1.2.5. & $\begin{array}{l}\text { Mangka sejatine rugi } \\
\text { 'padahal sebenarnya rugi' } \\
\text { masyarakat ngenteni gebragane Erick Thohir }\end{array}$ \\
& $\begin{array}{l}\text { 'masyarakat menunggu gebrakan Erick } \\
\text { Thohir' }\end{array}$
\end{tabular} \\
\hline 2.1.3. Metaphor & \begin{tabular}{|l} 
2.1.3.1. \\
2adi papane para budi candhala nak kumanak \\
2jadi tempat orang-orang bersifat buruk \\
beranak-pinak' \\
ngresiki BUMN saka jamur-jamur parasite \\
2membersihkan jamur-jamur parasitnya' \\
2.1.3.3. kementerian sing wis samapta mlayu banter \\
'kementerian yang sudah siap berlari \\
kencang' \\
masyarakat ngenteni gebragane Erick Thohir \\
'masyarakat menunggu gebrakan Erick \\
Thohir'
\end{tabular} \\
\hline 2.1.4. $\quad$ Swearing & $\begin{array}{l}\text { 2.1.4.1 luwih becik dikipatake } \\
\text { 'lebih baik dibuang (dengan cara kasar yaitu } \\
\text { dikibaskan)' }\end{array}$ \\
\hline 2.2. Focus & \\
\hline 2.2.1. Sharphen & 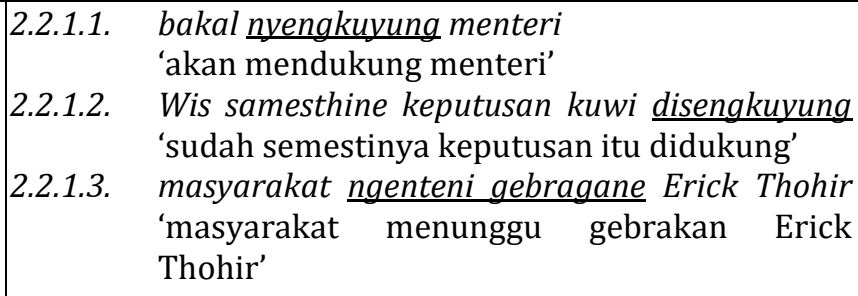 \\
\hline 2.2.2. Soften & $\begin{array}{l}\text { masyarakat ngenteni gebragane Erick Thohir } \\
\text { 'masyarakat menunggu gebrakan Erick } \\
\text { Thohir' } \\
\text { Erick Thohir stel kenceng } \\
\text { 'Erick Thohir berpikir keras' }\end{array}$ \\
\hline \multicolumn{2}{|l|}{ 3. Source of appraisal } \\
\hline 3.1. Monogloss & $\begin{array}{l}\text { Wis samesthine keputusan kuwi disengkuyung. } \\
\text { 'sudah semestinya keputusan itu didukung' } \\
\text { Pancen yen ngomongake masalah BUMN ora } \\
\text { bakal ana enteke } \\
\text { 'memang jika membicarakan masalah BUMN } \\
\text { tidak akan ada habisnya' }\end{array}$ \\
\hline 3.2. Heterogloss & $\begin{array}{l}\text { asring rinungu menawa Kementerian BUMN dadi } \\
\text { incerane klompok tinamtu } \\
\text { 'sering terdengar kalau Kementerian BUMN jadi } \\
\text { incarannya kelompok tertentu' }\end{array}$ \\
\hline
\end{tabular}




\begin{tabular}{|c|c|c|}
\hline & $\begin{array}{l}3.3 .2 .2 \\
3.3 .2 .3 \\
3.3 .2 .4\end{array}$ & $\begin{array}{l}\text { miturut ekonom Rizal Ramli } \\
\text { 'menurut ekonom Rizal Ramli' } \\
\text { Ora sethithik pimpinan sawijining BUMN } \\
\text { 'tidak sedikit pimpinan salah satu BUMN' } \\
\text { Sebab kabeh duwe kapentingan entuk dhuwit } \\
\text { saka kana } \\
\text { 'sebab semua punya kepentingan mendapatkan } \\
\text { uang dari sana' } \\
\text { Presidhen mundhut BUMN sing ora sehat luwih } \\
\text { becik dikipatake } \\
\text { 'Presiden berpendapat BUMN yang tidak sehat } \\
\text { lebih baik dibuang' } \\
\begin{array}{l}\text { Praktek-praktek reged kaya ngono kuwi asring } \\
\text { kedadeyan }\end{array} \\
\text { 'praktik-praktik kotor seperti itu lebih sering } \\
\text { terjadi' } \\
\text { masyarakat sing wis sebel karo praktek-praktek } \\
\text { korupsi } \\
\text { 'masyarakat yang sudah jengkel dengan } \\
\text { praktik-praktik korupsi' }\end{array}$ \\
\hline
\end{tabular}

Teks editorial Pangudarasa ditulis oleh salah satu wartawan majalah Panjebar Semangat yaitu Ksw. Berdasarkan teks editorial tulisannya tersebut dapat diasumsikan bahwa penulis mendukung penuh langkah Menteri Erick Thohir memberhentikan Direktur Utama PT Garuda Indonesia yaitu Ari Askhara dengan tidak hormat karena melakukan beberapa tindakan negatif yang merugikan banyak pihak terutama negara. Salah satunya adalah penyelundupan barang mewah yaitu moge (motor gede) Harley Davidson dan Brompton di pesawat Garuda. Hal itu dikuatkan dengan pemarkah appraisal affect positif tersirat yaitu:

\subsubsection{Wis samesthine keputusan kuwi disengkuyung}

'sudah semestinya keputusan itu didukung'

Data di atas menunjukkan penulis menyetujui dan mendukung langkah Menteri Erick Thohir pada frasa wis samesthine 'sudah seharusnya' dan kata disengkuyung 'didukung'. Namun pada frasa wis samesthine terdapat asumsi pro kontra. Ada banyak pihak yang mendukung langkah tersebut, tetapi ada juga yang menentang keputusan Menteri untuk memberhentikan Direktur PT Garuda Indonesia. Pihak yang mendukung dapat dipastikan berasal dari pemerintah dan masyarakat pada umumnya. Sementara itu, pihak yang menentang adalah oknum-oknum yang terlibat dan secara langsung merasakan keuntungan dengan berlangsungnya praktik-praktik kotor Ari Askara. Hal tersebut dapat dibuktikan melalui data berikut.

\subsubsection{4 masyarakat ngenteni gebragane Erick Thohir 'masyarakat menunggu gebrakan Erick Thohir'}

Affect positif tersirat muncul dalam klausa masyarakat ngenteni gebragane Erick Thohir 'masyarakat menunggu gebrakan Erick Thohir'. Dari pemarkah appraisal tersebut diasumsikan masyarakat memberikan dukungan penuh terhadap keputusan Menteri tersebut. Sementara itu, pihak yang kontra dapat dibuktikan dengan munculnya piranti appraisal berikut.

\subsubsection{4 klompok tinamtu ngunthet dhuwite negara}


'kelompok tertentu mencuri uang negara'

Moral judgements negatif langsung muncul dalam data tersebut, yaitu ditandai dengan klausa klompok tinamtu ngunthet dhuwite negara 'kelompok tertentu mencuri uang negara', frasa kelompok tertentu menunjukkan bahwa terbukti ada oknum yang bertindak buruk dengan mencuri uang negara. Tentu saja kelompok-kelompok seperti inilah yang kontra dengan langkah Erick Thohir memutus benang merah dengan mencopot Direktur PT Garuda Indonesia Ari Askhara. Namun tugas Erick tidaklah ringan, karena harus berhadapan dengan oknum-oknum yang licik dan culas. Hal tersebut didukung dengan pernyataan berikut.

\subsubsection{Erick duwe jejibahan ora entheng \\ 'Erick memiliki tugas yang tidak ringan'}

Pernyataan penulis tersebut mengandung moral judgement negatif langsung dengan dibuktikan pada frasa jejibahan ora entheng 'tanggung jawab yang tidak ringan'. Sebenarnya penulis yakin akan ketegasan Erick dalam menindak hal-hal yang tidak sesuai dengan ketentuan. Namun tampaknya penulis tetap meragukan kebijakan-kebijakannya akan mendapat dukungan sepenuhnya dari lingkungan BUMN yang terbiasa dengan praktik-praktik kotor tersebut. Tidak dapat dipungkiri BUMN menjadi lahan basah yang banyak menghasilkan uang. Hal tersebut dibuktikan dengan penyataan penulis berikut.

\subsubsection{5 asete BUMN nggayuh Rp. 8.000 trilyun 'asetnya BUMN mencapai Rp. 8.000 trilyun'}

Aset BUMN mencapai Rp. 8.000 trilyun dikategorikan pada pemarkah appraisal jenis force intensifier menguatkan bahwa BUMN merupakan lahan basah yang menghasilkan banyak uang. Terlebih lagi bagi oknum yang tidak bertanggung jawab akan mengincar posisi ini. Berikut adalah pemarkah pembukti pernyataan tersebut.

\subsubsection{1 asring rinungu menawa Kementerian BUMN dadi incerane klompok tinamtu 'sering terdengar kalau Kementerian BUMN jadi incarannya kelompok tertentu'}

Klausa BUMN dadi incerane klompok tinamtu 'BUMN jadi incaran klompok tertentu' dikategorikan sebagai source of appraisal dengan jenis heterogloss. Pemarkah heteroglos merupakan pendapat yang bersumber dari berbagai pihak yang dibuktikan dengan frasa asring rinungu 'sering terdengar'. Asumsi ini mendukung pernyataan banyak orang yang membicarakan dan mengetahui bahwa posisi BUMN jadi incaran banyak pihak yang akan menyalahgunakan jabatan tersebut.

\subsubsection{BUMN bakal dadi papane para budi candhala \\ 'BUMN akan jadi tempat orang yang bersifat buruk'}

Pemarkah moral judgement negatif langsung tersebut menguatkan pernyataan berbagai pihak yang memprediksi masa depan BUMN. Frasa para budi candhala 'orang yang bersifat buruk' menguatkan adanya oknum yang mengincar posisi BUMN. Hal tersebut akan menjadi sebuah kenyataan, apabila tidak ada tindakan tegas memutus mata rantai korupsi yang mengakar. Tidaklah mudah tanggung jawab yang diemban oleh Erick Thohir sebagai pemain baru di BUMN, karena harus melakukan bersih-bersih di segala aspek. Berikut ungkapan penulis yang mewakili argumen tersebut.

\subsubsection{1 ngresiki BUMN saka jamur-jamur parasite}


'membersihkan BUMN dari jamur-jamur parasitnya'

Kata ngresiki 'membersihkan' dan frasa jamur-jamur parasite 'jamur-jamur parasitnya' menjadi pemarkah moral judgement negatif tersirat. Secara tidak langsung penulis ingin mengungkap bahwa BUMN dalam kondisi yang tidak sehat dan banyak oknum yang memanfaatkan kesempatan. Oleh karena itu, sudah saatnya kondisi semacam itu harus disudahi dengan tindakan bersih-bersih. Bersih-bersih di sini adalah bukan makna sesungguhnya membersihkan Gedung BUMN dengan segala macam peralatan kebersihan, tetapi bersih-bersih yang dimaksud adalah menyingkirkan oknum (jamur parasit) ke tempat yang semestinya.

\subsubsection{7 pranyata akeh 'tikuse' \\ 'nyatanya banyak tikusnya'}

Frasa jamur-jamur parasite 'jamur-jamur parasitnya' ditegaskan ulang dengan kata tikuse 'tikusnya'. Hal itu menunjukkan penulis ingin memunculkan appreciation negatif dengan memberikan penekanan pada diksinya. Tikus merupakan hewan yang dijadikan simbol koruptor. Oleh karena itu, jamur dan tikus diasumsikan sebagai oknum yang tidak bertanggung jawab. Selain dua pemarkah tersebut, oknum juga digambarkan dengan frasa budi candhala 'bersifat buruk' seperti yang terdapat dalam data berikut.

\subsubsection{1 para budi candhala nak kumanak}

'orang-orang yang bersifat buruk beranak-pinak'

Perangkat appraisal berupa amplification dengan jenis force intensifier digunakan penulis, agar menguatkan karakter negatif pada oknum. Pengulangan dengan diksi yang bervariasi membuat pembaca tidak jenuh, namun merekam dengan kuat kata-kata yang dianggap unik dalam mewakili persepsi penulis tersebut.

\subsubsection{Erick Thohir diajab ora duwe sesanggan politik}

'Erick Thohir diharap tidak memiliki beban politik'

Pemarkah personal judgement positif langsung yang digunakan penulis untuk menggambarkan sosok Erick Thohir muncul pada klausa Erick Thohir diajab ora duwe sesanggan politik 'Erick Thohir diharap tidak memiliki beban politik'. Dapat diasumsikan alasan tersebut dijadikan Presiden untuk mengangkatnya sebagai Menteri BUMN.

\subsubsection{Dheweke professional murni}

'Dia professional murni'

Persepsi penulis dan asumsi alasan Presiden dikuatkan dengan klausa dheweke professional murni 'dia professional murni'. Sebagai seorang professional murni, Erick Thohir mendapat pengharapan besar dari masyarakat, yakni dengan memunculkan intensifier sebagai berikut.

\subsubsection{0 pangarep-arep kang gedhe \\ 'harapan yang besar'}

Pemarkah intensifier tersebut mewujudkan harapan besar dari masyarakat untuk menjadikan BUMN menjadi lebih bersih. Erick Thohir dinilai sebagai seorang yang tidak lagi mengejar harta, karena sudah memiliki kekayaan yang fantastis. Sebagai seorang pengusaha sukses, memiliki harta yang berlimpah, diharapkan tidak lagi tertarik melakukan korupsi. 


\subsubsection{Dhuwite sing akeh \\ 'uangnya yang banyak'}

\subsubsection{Dhuwite sing akeh merga kuwat tuku klub bal-balan}

'Uangnya banyak karena mampu membeli klub sepak bola'

\subsubsection{4 saengga ora duwe niyat korupsi \\ 'sehingga tidak memiliki niat untuk korupsi'}

Tiga data di atas menguatkan penggambaran sosok Menteri BUMN yang baru tersebut. Sosoknya yang bukan politikus tidak akan membatasi ruang geraknya. Latar belakang seorang pengusaha dapat diasumsikan akan melaksanakan tanggung jawabnya secara cermat agar tidak mendapatkan kerugian di masa mendatang, orientasinya adalah profit bagi negara. Kondisi finansial yang mapan diasumsikan oleh penulis dengan frasa dhuwite sing akeh 'uangnya yang banyak' bahkan bisa membeli klub sepak bola kenamaan, akan meneguhkan niatnya untuk tidak korupsi.

Berdasarkan analisis unsur-unsur appraisal yang terdapat dalam teks editorial Pangudarasa pada Majalah Panjebar Semangat edisi 21 Desember 2019, dapat disimpulkan bahwa penelitian ini memberikan penambahan terhadap gagasan Martin \& White (2005) tentang persepsi dan keberpihakan pada heteroglos. Aspek yang ditambahkan yakni piranti attitude ternyata dapat digunakan sebagai titik tumpu untuk menemukan tujuan penggunaan piranti amplification dan source of appraisal. Dominasi penggunaan appreciation dalam ekspresi keberpihakan merupakan strategi penutur untuk menyamarkan audiens yang dievaluasi secara langsung. Penutur atau penulis berpihak penuh pada salah satu sosok dengan memunculkan sisi positif karakter tersebut. Selain itu, sebagai penyeimbang karakter positif dimunculkan juga karakter negatif dari oknum yang disoroti sehingga tampak rasional ketika penutur berpihak pada hal yang dinilainya baik. Hal itu, sejalan dengan Fairclough (2001) yang melibatkan unsur sosiokultural dalam analisis wacana kritis.

Piranti force menjadikan teks editorial Pangudarasa terasa lebih akurat bagi pembacanya. Penggunaan konjungsi dirasa sudah tepat untuk menggambarkan alur opini dengan peristiwa faktual yang terjadi. Setelah membaca teks editorial tersebut, pembaca seperti mendapat pengaruh untuk ikut berpihak pada hal yang penutur sampaikan. Penulis menggunakan fungsi-fungsi bahasa tertentu untuk memengaruhi pembaca dengan berbagai penilaian yang telah disampaikan, sehingga pembaca cenderung akan ikut terpengaruh dengan fakta-fakta aktual namun subjektif yang dibacanya.

\section{SIMPULAN}

Berdasarkan hasil analisis data yang telah dilakukan, dapat disimpulkan bahwa: (1) piranti appraisal yang terdapat dalam teks editorial Pangudarasa dalam majalah Panjebar Semangat didominasi oleh appreciation sebanyak 42,55\%, judgement sebesar $36,17 \%$ serta unsur affect sebanyak 21,28\%; dan (2)pola kecenderungan persepsi penulis menunjukkan dukungan terhadap keputusan Menteri Erick Thohir dalam menangani kasus Garuda Airlines. Persepsi dukungan tersebut dikuatkan dengan penggunaan fungsi bahasa untuk memengaruhi orang lain dengan memberikan penilaian langsung terhadap suatu hal dan penulis teks editorial Pangudarasa memiliki kecenderungan menceritakan hal sensitif atau masalah yang menimbulkan keprihatinan terhadap peristiwa-peristiwa yang terjadi di masyarakat. 


\section{DAFTAR PUSTAKA}

Ellyawati, HC. (2011). "Analisis wacana kritis teks berita kasus terbongkarnya perlakuan istimewa terhadap terpidana suap Arthalyta Suryani pada media online." The Messenger Vol III, No. 1 Edisi Juli 2011 (19-35).

Fairclough, Norman. (2001). Critical discourse analysis as a method in social scientific research in Methods of Critical Discourse Analysis (Ruth Wodak and Michael Meyereditors). London: Sage Publication Ltd.

Irlinda, AH, Santosa, R, Kristina, D. (2016). "Analisis terjemahan ekspresi solidaritas dan keberpihakan dalam teks konferensi pers dan siaran media tentang eksekusi narapidana (pendekatan teori appraisal)". Prasasti: Journal of Linguistics, Vol. 1, No. 2 November 2016 (187-209).

Martin, J.R. \& White, P.R.R. (2005). The language of evaluation: appraisal in English. New York: Palgrave Macmillan.

Nazhira, Rusyda, dkk. (2016). "Apraisal sikap dalam teks berita Surat Kabar Nasional." Jurnal Tutur, Vol. 2, No. 1 (1-14).

Panggabean, Sarma. (2016). "Evaluasi Bahasa tajuk rencana menggunakan kerangka apraisal oleh mahasiswa Program Studi Pendidikan Bahasa dan Sastra Indonesia FKIP Universitas HKBP Nommensen". Jurnal Ilmiah Dunia Ilmu Vol. 2, No. 3 Oktober 2016 (1535).

Pusparini, A, Djatmika, Riyadi Santosa. (2017). “Analisis sistem appraisal berita proses eksekusi Duo Bali Nine (pendekatan linguistik sistemik fungsional)”. Paramasastra Vol. 2, No. 2 September 2017 (193-208).

Sudaryanto. (2015). Metode dan aneka teknik analisis bahasa. Yogyakarta: Sanata Darma University Press. 